\title{
CERAMIDE FROM THE HORNS OF THE PUNCTATE DEER
}

G. B. Elyakov and R. V. Cherezova

Khimiya Prirodnykh Soedinenii, Vol. 4, No. 1, p. 47, 1968

The nonossifying horns of the punctate deer (Cervus nippon holtulerum) have long been used in Eastern medicine as a tonic agent. However, almost nothing is known about the chemical structure of the individual substances of the horns. A. B. Silaev [1] has found cholesterol in them; the presence of other groups of substances (lipids, proteins) has hardly been studied.

We: have begun a systematic investigation of the lipid fraction of the horns. By extraction with acetone, $1.4 \mathrm{~kg}$ of dry horns gave $40 \mathrm{~g}$ of total lipid fraction (TLF), which pharmacologists consider to possess physiological activity. The repeated chromatography of $40 \mathrm{~g}$ of TLF on silica gel in the ethyl acetate-petroleum ether system gave $500 \mathrm{mg}$ of a white crystalline substance with the composition $\mathrm{C}_{46} \mathrm{H}_{93} \mathrm{O}_{4} \mathrm{~N}, \mathrm{mp} 84-86^{\circ} \mathrm{C}$. IR spectrum: $1680 \mathrm{~cm}^{-1}, 3440,3630 \mathrm{~cm}^{-1}$.

Found, \%: C 77.2; H 13.03; N 1.93 .

The substance gives a positive reaction with dinitrofluorobenzene and does not react with ninhydrin which, together with IR spectroscopic data, indicates the presence of an amide bond in the substance. In actual fact, when the substance was treated with ethanolic potassium hydroxide, hydrolysis took place smoothly. The free base was extracted with a $2 \%$ solution of isoamyl alcohol in heptane [2] and, after recrystallization from petroleum ether, was obtained in the crystalline state with $\mathrm{mp} 81-82^{\circ} \mathrm{C}$. In its chromatographic behavior, the substance was identical with sphyngosine (slightly contaminated with dihydrosphyngosine) [3].

Found, \%: C 72.01; $\mathrm{H} 12.43$. Calculated for $\mathrm{C}_{18} \mathrm{H}_{37} \mathrm{O}_{2} \mathrm{~N}$ (sphyngosine), \%: C 72.19; $\mathrm{H} 12.48$.

According to the literature [2], the melting point of sphyngosine is $82.5-83^{\circ} \mathrm{C}$. The hydrolysate a iso yielded a fatty acid which was converted by treatment with diazomethane into the methyl ester.

Thus, the substance obtained is ceramide, its amount in the lipid fraction of horns being $1.25 \%$.

\section{REFERENCES}

1. S. M. Pavlenko and A. B. Silaev, "Pantokrin", Sojuzchimexport, USSR 9-13, 1960.

2. R. O. Brady and R. M. Burton, J. Neirochem., 1, no. 1, 18, 9, 1956.

3. N. K. Kochetkov, J. G. Zhukova, and J. S. Gluchoded, Biochim. et Biophys. Acta, 60, 431, 1962.

18 Septernber 1967

Institute of Biologically Active Substances, Far Eastern Branch, Siberian Division, AS USSR

UDC $577.15 / 17: 582.89$ COUMARINS OF THE ROOTS OF HERACLEUM WILHELMSII AND H. ASPERUM

E. D. Giorgobiani, N. F. Komissarenko, and E. P. Kemertelidze

Khimiya Prirodnykh Soedinenii, Vol, 4, No. 1, pp. 47-48, 1968

Twenty-one species of the genus Heracleum L. (Umbelliferae), which contain coumarin compounds, grow in the Caucasus .

The present paper gives the results of a study of the coumarin composition of the roots of two Heracleum species

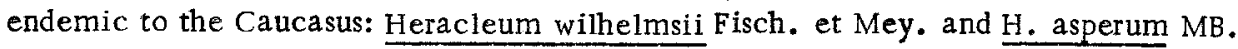

